\title{
Evaluation of Mechanical and Microstructural Properties of $\alpha$-Brass Alloy Produced from Scrap Copper and Zinc Metal through Sand Casting Process
}

\author{
Edward E. Igelegbai, Oluwaseun A. Alo, Adefemi O. Adeodu, Ilesanmi A. Daniyan \\ Department of Mechanical and Mechatronics Engineering, Afe Babalola University, Ado-Ekiti, Nigeria \\ Email: femi2001ng@yahoo.com, afolabiilesanmi@yahoo.com, seunalloy@yahoo.com, igelegbaiedward@gmail.com
}

How to cite this paper: Igelegbai, E.E., Alo, O.A., Adeodu, A.O. and Daniyan, I.A. (2017) Evaluation of Mechanical and Microstructural Properties of $\alpha$-Brass Alloy Produced from Scrap Copper and Zinc Metal through Sand Casting Process. Journal of Minerals and Materials Characterization and Engineering, 5, 18-28.

http://dx.doi.org/10.4236/jmmce.2017.51002

Received: September 21, 2016

Accepted: December 17, 2016

Published: December 20, 2016

Copyright $\odot 2017$ by authors and Scientific Research Publishing Inc. This work is licensed under the Creative Commons Attribution International License (CC BY 4.0).

http://creativecommons.org/licenses/by/4.0/

(c) (i) Open Access

\begin{abstract}
$\mathrm{Cu}-\mathrm{Zn}$ alloy (Brass) is widely used as an industrial material because of its excellent characteristics such as high corrosion resistance, non-magnetism and good forging ability. This paper evaluates the mechanical and microstructure properties of $\alpha$-brass alloy gotten from scrap copper and zinc metal, and compares the properties with normal $\alpha$-brass billets. Five different compositions of the $\alpha$-brass alloy (Cu-5\%Zn, Cu-10\%Zn, Cu-15\%Zn, Cu-20\%Zn, Cu-30\%Zn) were produced from scraps of copper wire and zinc batteries casing respectively by method of sand casting. The parts of the cast rods were machined to a specification of $60 \mathrm{~mm} \times 100 \mathrm{~mm} \times 300 \mathrm{~mm}$ on a lathe to obtain tensile test specimens. After homogenization annealing, the samples were heated in an electric furnace at $500^{\circ} \mathrm{C}$ for 3 hours. The samples were etched with ferric chloride solution for 20 seconds and sent for metallographic examination. The result of the hardness test shows variation in hardness of the cast $\mathrm{Cu}-\mathrm{Zn}$ alloys with increasing zinc content. The ductility and elongation of the $\alpha$-brass decrease with increasing zinc content. The colouration of the $\alpha$-brass changed from red to yellow as the zinc content increases. In conclusion, hard brass can be obtained from recycled $\mathrm{Cu}$ and $\mathrm{Zn}$ as compared to normal brass billets.
\end{abstract}

\section{Keywords}

Alloys, Alpha-Brass, Etching, Metallographic, Sand Casting

\section{Introduction}

Brass is a metal alloy made of copper and zinc [1], whose proportions can be varied to create a range of brasses with varying properties [2]. The formation of brass makes it a substitutional alloy i.e. atoms of the two constituents may re- 
place each other within the same crystal structure [1]. Brass has higher malleability compared to its counterpart bronze [1]. However, both may also include small proportions of a range of other elements including arsenic, phosphorus, aluminum, manganese and silicon [1]. Generally, it has low melting point of about $900^{\circ} \mathrm{C}$ to $940^{\circ} \mathrm{C}\left(1652^{\circ} \mathrm{F}\right.$ to $\left.1724^{\circ} \mathrm{F}\right)$ depending on its composition. Its flow characteristics make it a relatively easy material to cast. By varying the proportions of copper and zinc, the mechanical properties of the brass can be changed, producing hard and soft brasses. The density of brass is approximately 0.303 $\mathrm{lb} / \mathrm{inch}^{3}\left(8.4 \mathrm{grams} / \mathrm{cm}^{3}\right)$ [3]. Cu-Zn alloy is widely used as industrial materials because of their excellent characteristics such as balance of strength, ductility, high corrosion resistance, non-magnetism and good formability [4]. Due to the excellent mechanical properties and machinability, it finds good applications in plumbing fixtures and fittings, low pressure valves, gears, bearings, decorative hardware and architectural frames [5].

According to [1] [4], several factors like corrosion resistance of brass to harsh environment, use in musical instrument industries, germicidal and anti-microbial application have contributed to increasing demands for brass alloy. In particular, electrical and electronic components' market of high performance and multifunctional has increased, and the amount of brass alloys in these products has also enlarged [4]. On the other hand, a weight reduction of parts and product is strongly required for the energy efficiency improvement of transport equipment or miniaturization [4]. An effect of brass alloy part with a high specific gravity on the weight ratio of the total product is large [4]. It is possible to produce the small parts by using the high strength brass alloy. Thus, the weight of the product will be reduced significantly.

Today, almost $90 \%$ of all brass alloys are recycled [6] due to non-ferromagnetism. It can be separated from ferrous scrap by passing the scrap near a powerful magnet. Brass scrap is collected and transported to the foundry where it is melted and recast into billet. Billet is reheated and extruded into the desired form and size. The study is aimed at evaluating $\alpha$-brass obtained from scraps $\mathrm{Cu}$ and $\mathrm{Zn}$ so as to achieve the objectives of determining the microstructure and mechanical properties of the brass as compared to normal $\alpha$-brass billets.

\section{General Survey on Brass Prospects}

Ozgowiez et al. [7] examined the influence of the recrystallization annealing temperature on the microstructure and mechanical properties of brass $\mathrm{Cu} 30 \% \mathrm{Zn}$ subjected to cold deformation in the process of rolling at various degree of strain. The mechanical test shows that there was deterioration in the properties of the brass and an increase in the plastic properties as the recrystallization temperature was increasing within the range $400^{\circ} \mathrm{C}-650^{\circ} \mathrm{C}$ (Table 1 ).

Xie et al. [8] also made a similar contributions on $\alpha$-brass (Cu-38Zn-0.15Fe$0.08 \mathrm{~Pb}-0.5 \mathrm{Ni}$ ) (mass\%) by examine the effect of rotational speed during friction stir welding. With increasing rotational rates, the friction of the non-crystallization grains decreased while that of re-crystallized grains increased. The hardness 
Table 1. Investigations of the mechanical properties of brass (Cu30\% Zn) after cold rolling and recrystallization annealing.

\begin{tabular}{|c|c|c|c|c|c|c|}
\hline \multirow{2}{*}{$\mathrm{S} / \mathrm{N}$} & \multirow{2}{*}{$\begin{array}{c}\text { Temp of } \\
\text { Recrystilization }\end{array}$} & \multirow{2}{*}{$\begin{array}{c}\text { Degree of } \\
\text { Rolling (\%) }\end{array}$} & \multicolumn{3}{|c|}{ Mechanical Properties } & \multirow{2}{*}{$\mathrm{Z}(\%)$} \\
\hline & & & $\mathrm{R}_{\mathrm{m}}(\mathrm{Mpa})$ & $\mathrm{R}_{\mathrm{e}}(\mathrm{Mpa})$ & $\mathrm{A}(\%)$ & \\
\hline 1 & $300^{\circ} \mathrm{C}$ & 15.5 & 413 & 357.8 & 26.8 & 67.1 \\
\hline 2 & & 29.8 & 463.8 & 439.5 & 18.9 & 62.7 \\
\hline 3 & & 42.5 & 459 & 377 & 30 & 64.2 \\
\hline 4 & & 56.2 & 447.1 & 311.2 & 37.9 & 64.9 \\
\hline 5 & & 70.2 & 452.9 & 307 & 38.5 & 57.2 \\
\hline 6 & $400^{\circ} \mathrm{C}$ & 15.5 & 363.2 & 148.9 & 57 & 75.4 \\
\hline 7 & & 29.8 & 370.8 & 156 & 54.2 & 70 \\
\hline 8 & & 42.5 & 373.2 & 163.9 & 51.8 & 69.1 \\
\hline 9 & & 56.2 & 392.7 & 193.4 & 55.4 & 74.3 \\
\hline 10 & & 70.2 & 403.2 & 210.7 & 48.4 & 62.8 \\
\hline 11 & $500^{\circ} \mathrm{C}$ & 15.5 & 347.9 & 125.3 & 63.7 & 73.2 \\
\hline 12 & & 29.8 & 351.4 & 132.9 & 59 & 75.2 \\
\hline 13 & & 42.5 & 352.3 & 134.9 & 60.1 & 75.7 \\
\hline 14 & & 56.2 & 348.4 & 140.6 & 57.4 & 70.9 \\
\hline 15 & & 70.2 & 355.4 & 139.2 & 52.1 & 69.1 \\
\hline 16 & $650^{\circ} \mathrm{C}$ & 15.5 & 305.2 & 72.8 & 81.8 & 82.3 \\
\hline 17 & & 29.8 & 310.1 & 76.2 & 70 & 78.2 \\
\hline 18 & & 42.5 & 304 & 75.7 & 72.8 & 81.7 \\
\hline 19 & & 56.2 & 312.5 & 78.7 & 76 & 76 \\
\hline 20 & & 70.2 & 315.6 & 78.5 & 65.2 & 76.9 \\
\hline
\end{tabular}

Tensile Strength (Rm), Yield Point (Re), Increased Elongation (A), Necking (Z). Source: [7].

values in the nugget zones (NZs) were lighter than those in the parent material (PM). Increasing the rotational rates did not exert a noticeable effect on the tensile and yield strength of the welds but increased the elongation.

According to the investigation by [5] on $\alpha$-brass ( $\mathrm{Cu} 44 \% \mathrm{Zn}$ ), the experimental results on microhardness and microstructure after sand casting and heat treatment show improvement in the microstructure and yields strength of the $a-$ brass. Another recent significant contribution by Hishashi et al., [4] was achieved by studying the microstructure and mechanical properties of $\mathrm{Cu}-40 \%$ $\mathrm{Zn}$ brass alloy with 0.5 mass\% $\mathrm{Cr}$ additives and monolithic $\mathrm{Cu}-40 \% \mathrm{Zn}$ powder produced by water atomization process. These powders were consolidated by hot extrusion at various temperatures by considering the precipitation behaviour of $\beta$-phase and Cr. The results by the comparison show higher yield strength in brass alloy with $\mathrm{Cr}$ than the monolithic brass at the same extruded temperature. Solid solution of chromium on the $\mathrm{Cu}-40 \% \mathrm{Zn}-0.5 \mathrm{Cr}$ brass alloy extruded at a temperature is about twice as that of the same brass alloy extruded at a higher 
temperature. The strength impact of $\mathrm{Cr}$ solid solution was much effective compared to $\mathrm{Cr}$ precipitation strengthening. The grain size of extruded materials increased with increasing extrusion temperature (Figures 1-3).

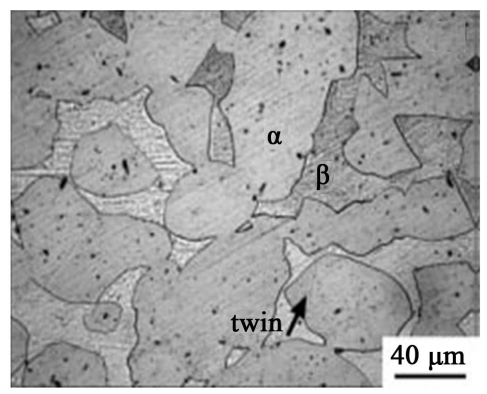

(a)

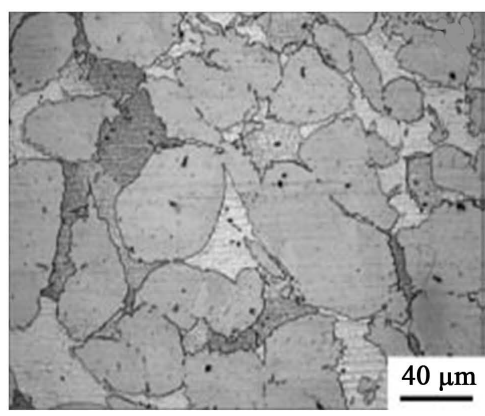

(b)

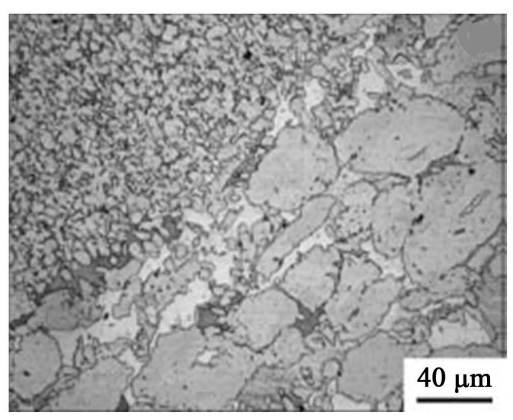

(c)

Figure 1. Microstructure of brass: (a) parent material (PM); (b) thermo-mechanical affected zone (TMAZ) at $600 \mathrm{rpm}$; (c) heat affected zone (HAZ) at $600 \mathrm{rpm}$. Source: [8].

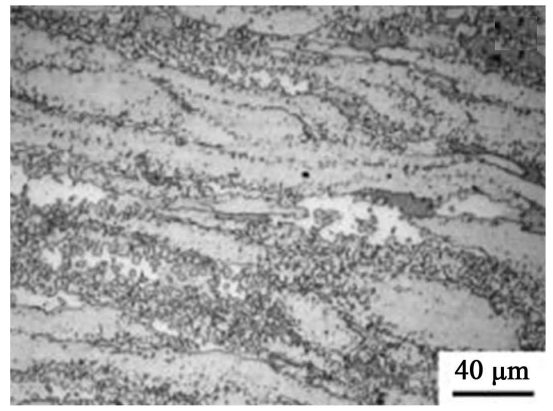

(a)

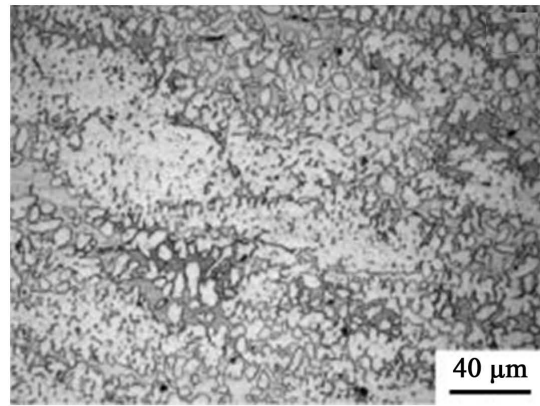

(c)

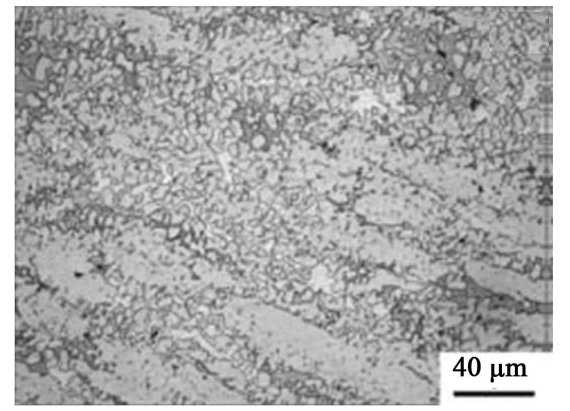

(b)

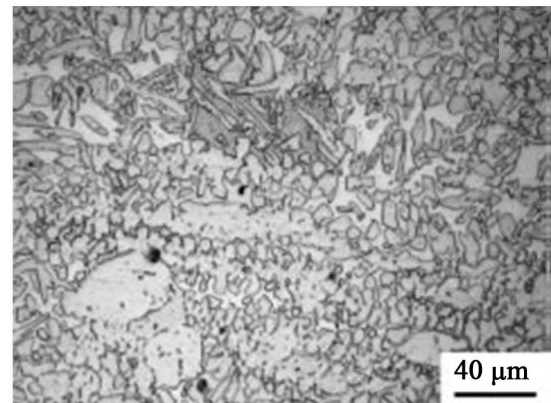

(d)

Figure 2. Microstructure of nugget zone (NZ 1) of friction stirred welding brass joints at (a) $400 \mathrm{rpm}$; (b) $600 \mathrm{rpm}$; (c) $800 \mathrm{rpm}$; (d) $1000 \mathrm{rpm}$. Source: [8]. 


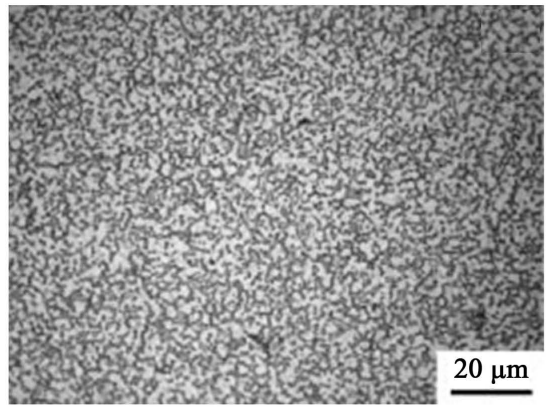

(a)

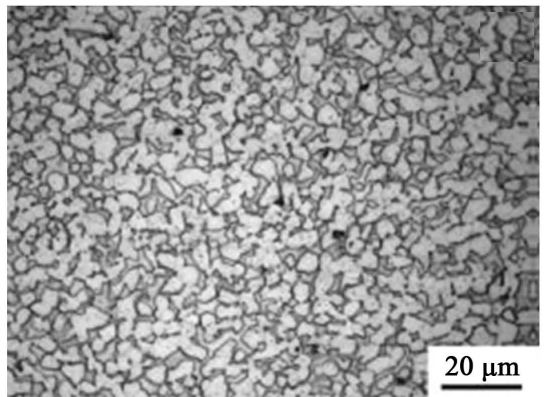

(c)

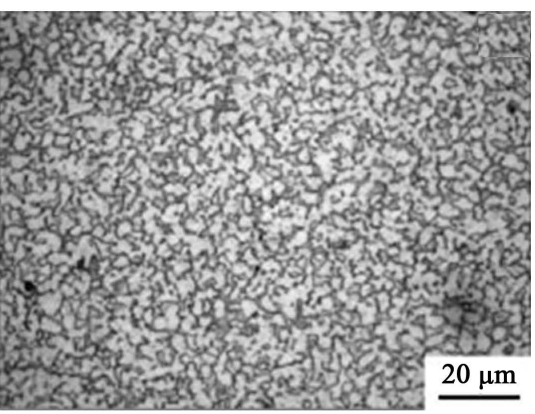

(b)

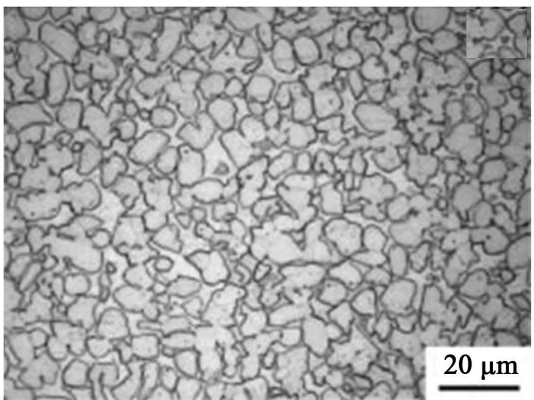

(d)

Figure 3. Microstructure of nugget zone 2 of friction stirred welding brass joints at (a) $400 \mathrm{rpm}$; (b) $600 \mathrm{rpm}$; (c) $800 \mathrm{rpm}$; (d) $1000 \mathrm{rpm}$. Source: [8].

\section{Experimental Procedure}

The $\mathrm{Cu}$ and $\mathrm{Zn}$ metals were purchased as scraps from copper wire and zinc battery casing respectively. Five different compositions of the alloy were prepared to give $\mathrm{Cu}-5 \% \mathrm{Zn}, \mathrm{Cu}-10 \% \mathrm{Zn}, \mathrm{Cu}-15 \% \mathrm{Zn}, \mathrm{Cu}-20 \% \mathrm{Zn}$ and $\mathrm{Cu}-30 \% \mathrm{Zn}$ alloy respectively. The total mass for each weight percentage was weighed to $1.5 \mathrm{~kg}$. The alloys were prepared by method of sand casting. The sequence of production process involved in the casting is as follows: pattern making, mould and core making, casting, demoulding, removal of runner/riser and cast cleaning (Table 2).

The furnace charge was calculated using Equation (1):

$$
R_{x}=(\% \text { of } X \text { in the melt }) T_{m}
$$

where $X=$ constituent $(\mathrm{Cu}$ or $\mathrm{Zn})$;

$R_{X}=$ required mass of the constituent in the melt;

$T_{m}=$ total mass of melt.

Parts of the cast rods were machined on a lathe to obtain the tensile test specimens. The rods were machined down to test specifications of $60 \mathrm{~mm} \times 100$ $\mathrm{mm} \times 300 \mathrm{~mm}$ as shown in the Figure 4 . The cast samples were subjected to homogenization annealing in order to homogenize the composition. They were heated in an OMSZON electrical furnace which was set to a temperature of $500^{\circ} \mathrm{C}$. The samples were soaked at this temperature for $3 \mathrm{hrs}$ and then allowed to cool slowly in the furnace. The grinding of each test sample was carried out under running water to avoid over heating of the sample with grinding machine 


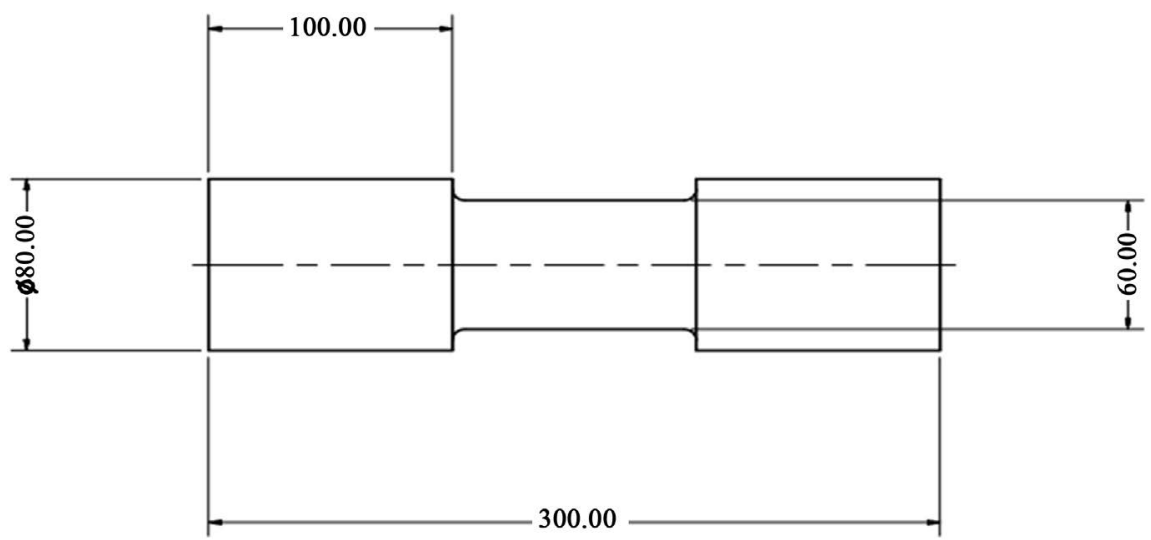

Figure 4. Working drawing of tensile test piece.

Table 2. Furnace charge calculation for $\mathrm{Cu}-\mathrm{Zn}$ alloys.

\begin{tabular}{cccc}
\hline Alloy & Copper $(\mathrm{Kg})$ & Zinc $(\mathrm{Kg})$ & Total Mass $(\mathrm{Kg})$ \\
\hline $\mathrm{Cu}-5 \% \mathrm{Zn}$ & 1.425 & 0.075 & 1.5 \\
$\mathrm{Cu}-10 \% \mathrm{Zn}$ & 1.35 & 0.15 & 1.5 \\
$\mathrm{Cu}-15 \% \mathrm{Zn}$ & 1.275 & 0.225 & 1.5 \\
$\mathrm{Cu}-20 \% \mathrm{Zn}$ & 1.2 & 0.3 & 1.5 \\
$\mathrm{Cu}-30 \% \mathrm{Zn}$ & 1.125 & 0.375 & 1.5 \\
Total & 6.375 & 1.125 & 7.5 \\
\hline
\end{tabular}

which consist of a set of emery papers of successive grades (240,320, 400 and 600) from coarse to finest. The subsequent grinding was done at an angle of $90^{\circ}$ to the previous. In order to obtain a perfectly flat and mirror like surface suitable for metallographic examination, samples were polished using ECONET II polishing deck with emery cloth mounted on a rotating disc. Each sample was held with a gently pressure against the alumina impregnated cloth. While the process is going on, constant flow of water was maintained to wash the wear debris. The prepared polished surface of each sample was etched with ferric chloride solution for 20 seconds, and then dipped in concentrated nitric acid to remove stains. The as-received and etched samples were mounted on ACCUSCOPE metallographic microscope and examined using a magnification of $\times 400$.

\subsection{Hardness Measurement}

The as-received samples and cast alloys were subjected to the hardness test using brinell hardness test accessory of the Mensanto Hounsfield Tensometer. Before the Tensometer was used, the compression attachments were mounted on the machine. After the whole setup, the corresponding Brinell hardness number was then calculated using the formula shown in the Equation (2)

$$
B H N=\frac{2 P}{\pi D\left(D-\sqrt{\left(D^{2}-d^{2}\right)}\right)}
$$


where $P$ = applied load;

$D=$ diameter of the indenter;

$d=$ diameter of the impression.

\subsection{Tensile Measurement}

Samples from as-received and cast brass alloys that had been machined into tensile test pieces were subjected to tensile tests with the aid of a Monsanto universal testing machine. The test was carried out to determine the response of samples under the application of increasing stresses. Some properties of the alloys that were studied are as follows; yield stress, percentage elongation, reduction in area and ultimate tensile stress.

\section{Results and Discussion}

\subsection{Hardness Test}

The result of the hardness test was presented in Table 3. Also Figure 5 shows the variation in hardness of the cast $\mathrm{Cu}-\mathrm{Zn}$ alloys with increasing zinc content.

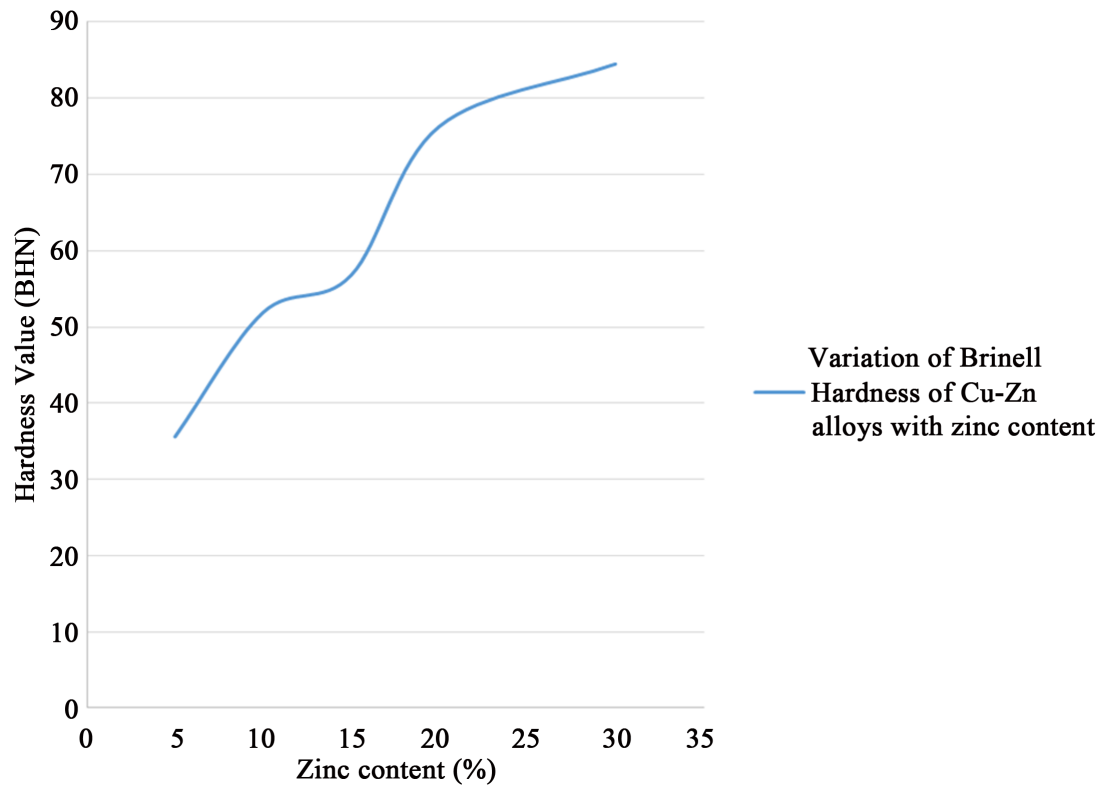

Figure 5. Variation of $\mathrm{Cu}-\mathrm{Zn}$ alloys with increasing zinc content.

Table 3. Results of the hardness test.

\begin{tabular}{cc}
\hline Sample & Brinell Number (HBR) \\
\hline Control sample & 107 \\
$\mathrm{Cu}-5 \% \mathrm{Zn}$ & 35.6 \\
$\mathrm{Cu}-10 \% \mathrm{Zn}$ & 51.9 \\
$\mathrm{Cu}-15 \% \mathrm{Zn}$ & 56.8 \\
$\mathrm{Cu}-20 \% \mathrm{Zn}$ & 76.3 \\
$\mathrm{Cu}-30 \% \mathrm{Zn}$ & 84.5 \\
\hline
\end{tabular}


As observed in Figure 4, the hardness value of the alloys increases as the zinc content increases. In the hardness test, severe plastic flow has been concentrated in the localized region directly below the indentation, outside of which the material still behaves elastically. Directly below the indentation, the density of the particles increased locally, compared to the regions away from the depression.

Since plastic deformation in crystals is caused by the motion of dislocations, any obstacle to dislocation motion will hinder deformation and the crystal is thereby strengthened [9]. Therefore, the increase in the hardness values of the alloys with increase in zinc content is attributable to solute hardening caused by the zinc solute atoms.

\subsection{Tensile Test}

The result of the tensile test was presented in the Table 4. The table shows the ultimate tensile strength (UTs), yield strength, and percentage elongation (\% EL) of the sample

It can be observed from Table 4, that the yield strength and ultimate tensile strength of the cast alloy samples initially increased with increase in zinc content and then decreased, with a maximum at $15 \mathrm{wt} \%$ Zinc. Also, the percentage elongation increased with increase in zinc content up to $20 \mathrm{wt} \% \mathrm{Zinc}$, and then decreased. Therefore, the alloy with $20 \mathrm{wt} \%$ Zinc has the highest ductility (Figure 6).

Cu : Control, $10 \% \mathrm{Zn}, 15 \% \mathrm{Zn}, 20 \% \mathrm{Zn}, 30 \% \mathrm{Zn}$
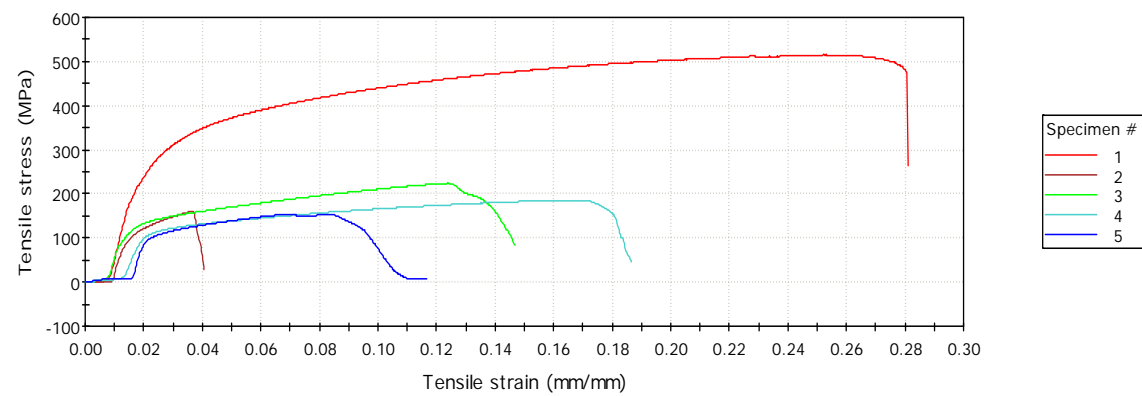

Figure 6. Modulus of elasticity of the alloy according to increasing zinc content.

Table 4. Tensile strength variation according to increasing zinc content.

\begin{tabular}{cccccccc}
\hline Sample & $\begin{array}{c}\text { Initial } \\
\text { Length } \\
\mathrm{L}_{0}(\mathrm{~mm})\end{array}$ & $\begin{array}{c}\text { Final } \\
\text { Length } \\
\mathrm{L}_{\mathrm{f}}(\mathrm{mm})\end{array}$ & $\begin{array}{c}\text { Yield } \\
\text { Load } \\
(\mathrm{N})\end{array}$ & $\begin{array}{c}\text { Tensile } \\
\text { Load } \\
(\mathrm{N})\end{array}$ & $\begin{array}{c}\text { Yield } \\
\text { Strength } \\
(\mathrm{Mpa})\end{array}$ & $\begin{array}{c}\text { UTs } \\
(\mathrm{Mpa})\end{array}$ & $\%$ EL \\
\hline Control sample & 30 & 37.59 & 6476.33 & 5969.14 & 515.37 & 425.01 & 25.31 \\
Cu-10\%Zn & 30 & 31.10 & 2010.78 & 443.96 & 160.01 & 35.33 & 3.67 \\
Cu-15\%Zn & 30 & 33.72 & 2815.40 & 1106.55 & 224.04 & 88.06 & 12.39 \\
Cu-20\%Zn & 30 & 34.98 & 2334.50 & 615.48 & 185.77 & 48.98 & 16.58 \\
Cu-30\%Zn & 30 & 32.18 & 1931.24 & 75.21 & 153.68 & 5.98 & 7.03 \\
\hline
\end{tabular}




\subsection{Micrograph of the Samples}

From Figures 7-12, micrographs of the various alloys reveal the presence of a single solid phase which consists of a solid solution of zinc in alpha copper. Alpha brasses containing up to $20 \% \mathrm{Zn}$ are reddish in colour. Above $20 \%$, the brass is yellow in colour [10]. This is expected because based on the $\mathrm{Cu}-\mathrm{Zn}$ phase diagram, zinc has complete solid solubility in copper up to $35 \%$ [11].

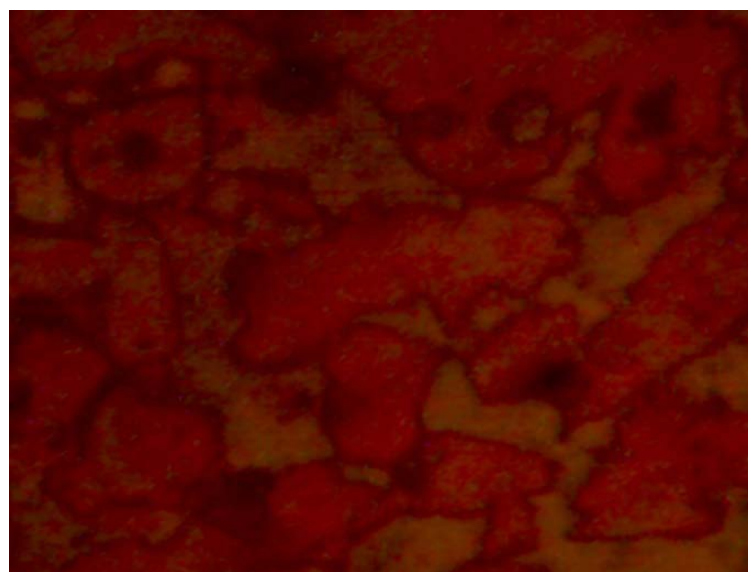

Figure 7. Micrograph of the as-received $\mathrm{Cu}-\mathrm{Zn}$ alloy $(\times 400)$.

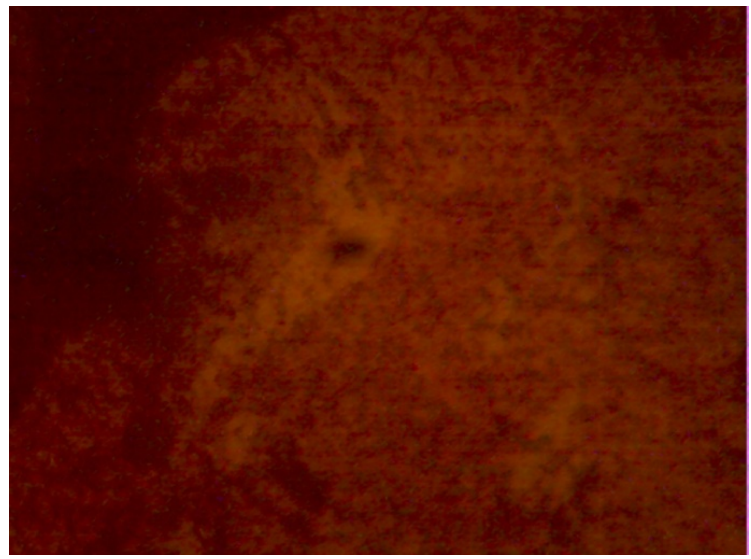

Figure 8. Micrograph of Cu 5\% Zn alloy $(\times 400)$.

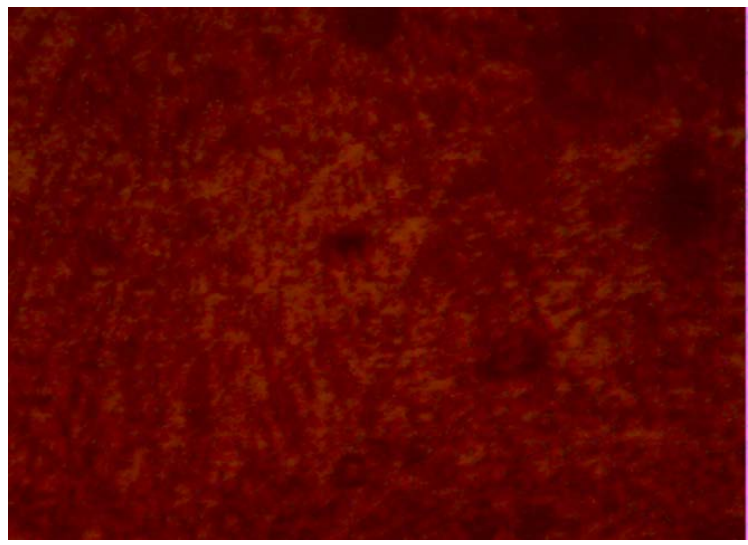

Figure 9. Micrograph of $\mathrm{Cu} 10 \% \mathrm{Zn}$ alloy $(\times 400)$. 


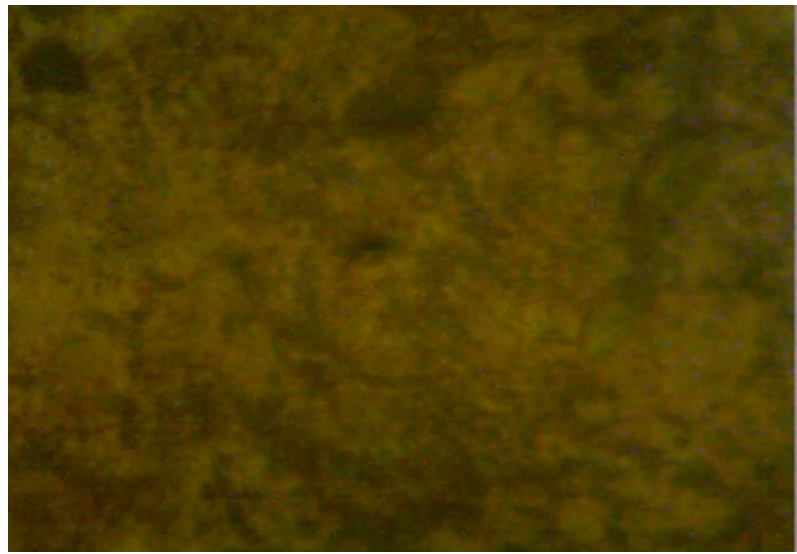

Figure 10. Micrograph of $\mathrm{Cu} 15 \% \mathrm{Zn}$ alloy $(\times 400)$.

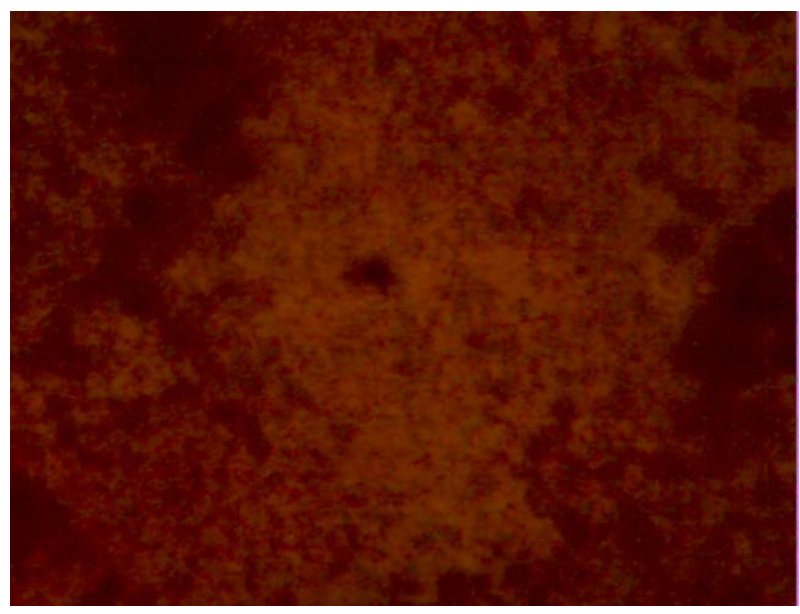

Figure 11. Micrograph of $\mathrm{Cu} 20 \% \mathrm{Zn}$ alloy $(\times 400)$.

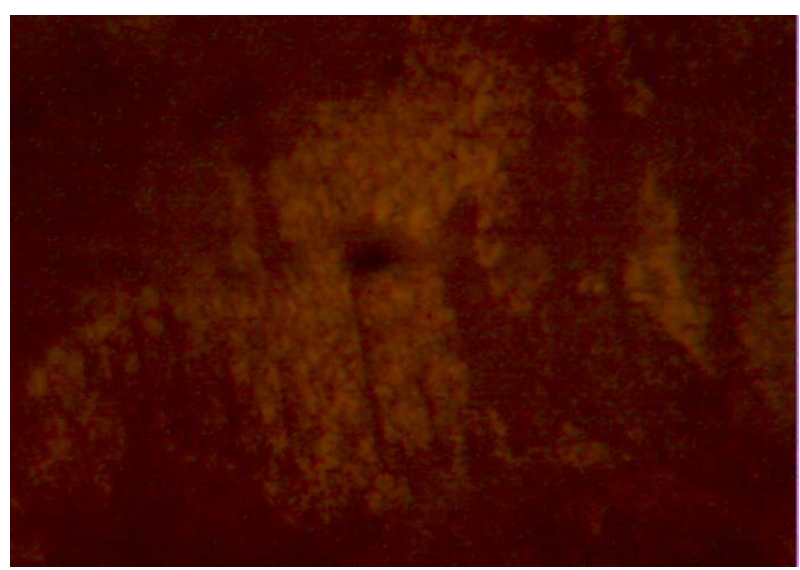

Figure 12. Micrograph of $\mathrm{Cu} 30 \% \mathrm{Zn}$ alloy $(\times 400)$.

\section{Conclusions}

Hardness of the cast brass samples made from recycled copper and zinc metals increased with increase in zinc content which shows that, the higher the recycled zinc used in casting brass alloys, the harder the brass obtained.

Brass alloys made from recycled copper and zinc were seen to possess low 
tensile strength and ductility with increase in brittleness as the zinc content increased. This is an indication that when more zinc is added during the casting of copper alloys, for the production of brass, the brass obtained will have less tensile strength, low ductility, and high degree of brittleness.

Generally an increase in the hardness of the cast brass obtained brought about an equal decrease in the tensile strength and ductility of the metal. Thus, in order to obtain an optimum brass cast, the zinc added to the copper must be at an optimum value. Therefore, recycled copper and zinc can be applied in brass production for engineering applications.

\section{Recommendations}

Based on the results obtained in this work, it is therefore recommended that the hardness property of $\mathrm{Cu}-\mathrm{Zn}$ alloys can be improved by addition zinc. However, further research work is required to determine other mechanical properties of the alloys (such as compression strength and impact strength) in order to obtain the optimum contents for $\mathrm{Cu}-\mathrm{Zn}$ alloys which give the best combination of mechanical properties.

\section{References}

[1] Brass Overview (2015). www.wikkipedia/brassoverview

[2] Khurmi and Gupter (2004) Engineering Designer, 30, 6-9.

[3] ad Roger, W. (2009) Mass, Weight, Density or Specific Gravity of Different Metals. Density of Materials. SImetric.co.uk., United Kingdom. https://www.simetric.co.uk/si metals.htm

[4] Hisashi, I., Shufeng, L., Atsumu, H., Kosaka, Y., Kojima, A., Umeda, J. and Kondoh, K. (2009) Mechanical Properties and Machinability of Extruded Cu-40\% Zn Brass Alloy with Bismuth via Powder Metallurgy Process. Transaction of JWRI, 38, 1-6.

[5] Hamizah, B.N. (2010) Investigation of Brass Microstructure and Mechanical Properties Using Metal Casting. B. Tech Dissertation. Faculty of Mechanical Engineering. University of Malaysia Pahang.

[6] Ashby, M.F. and Johnson, K. (2002) Materials and Design: The Art and Science of Material Selection in Product Design. Butterworth-Heinemann, Oxford, 223.

[7] Ozgowicz, W., Kalinowska, E.O. and Grzegorczyk, B. (2010) The Microstructure and Mechanical Properties of the Alloy Cu-30\% Zn after Recrystallizion Annealing. Journal of Achievements in Materials and Manufacturing Engineering, 40, 1-10.

[8] Xie, G.M., Ma, Z.Y. and Geng, L. (2008) Effects of Friction Stir Welding Parameters on Mechanical and Microstructure Properties of Brass Joint. Japan Institute of Metals. Material Transactions, 49, 1698-1701. https://doi.org/10.2320/matertrans.MRP2008089

[9] Ajaja, O. (2014) Material Science and Engineering. Lamlad Publication, Ado-Ekiti, Nigeria, 108.

[10] Raghavan, V. (2012) Physical and Metallurgy: Principle and Practice. 2nd Edition, PHI Learning Private Limited, New Delhi.

[11] Smith, W.F. and Hashemi, J. (2010) Foundation of Materials Science and Engineering. 5th Edition, McGraw Hill, New York, 4. 
Submit or recommend next manuscript to SCIRP and we will provide best service for you:

Accepting pre-submission inquiries through Email, Facebook, LinkedIn, Twitter, etc. A wide selection of journals (inclusive of 9 subjects, more than 200 journals)

Providing 24-hour high-quality service

User-friendly online submission system

Fair and swift peer-review system

Efficient typesetting and proofreading procedure

Display of the result of downloads and visits, as well as the number of cited articles Maximum dissemination of your research work

Submit your manuscript at: http://papersubmission.scirp.org/

Or contact jmmce@scirp.org 